in a place of window framing to the wall of residential and public buildings, which were massively produced in the second half of the twentieth century. Condensation can be avoided by raising the surface temperature of the inner window jamb extensions. This can be done by adding an additional insulation or displacement of the block frame window inside the building. The aim of the work is to calculate the appropriate values of the displacement of the block frame window inside the wall of different types for the climatic conditions of the Kirovograd region.

The framing of metal-plastic windows to the walls of various structures that were produced in the second half of the twentieth century are analyzed. The insulation is performed in accordance with DBN B.2.631-2016. The lowest design temperature of the coldest five-day period within the territory of the Kirovograd Region is $-24^{\circ} \mathrm{C}$. As a safety margin, the dew point temperature for residential and public buildings for various purposes is taken to be $+11^{\circ} \mathrm{C}$. Finite element modeling in the THERM program environment made it possible to construct the temperature fields of the framing of metal-plastic windows to the walls of various structures and to obtain the very temperature of the inner window jamb extensions at various positions of the window frame within the wall. For each of the nodes examined, the possibility of condensation on the inner surfaces of the walls was established taking into account the position of window frame within the wall.

As a result of the studies, it was found that the nodes of the side framing of the windows to the brick and panel walls of civil buildings without additional facade insulation do not meet the requirements for thermal reliability according to the condensation criterion. Facade insulation of existing or new walls, made in accordance with the requirements of DBN B.2.6-31-2016 "Thermal insulation of buildings", in almost all cases guarantees the absence of condensation on the internal surfaces of window jambs.

outside walls, windows framing, surface temperature, condensation

Oleksandr Semko, Prof., DSc., Anton Hasenko, Assoc. Prof., PhD. tech. sci., Aleksey Fenko, Assoc. Prof., PhD. tech. sci. Educational and Scientific Institute of Architecture and Construction, National University "Yuri Kondratyuk Poltava Polytechnic", Poltava, Ukraine e-mail: gasentk@gmail.com

J Godwin Emmanuel B. Arch., Pursuing PhD, Assoc. Prof., Res. sch. C.A.R.E. School of Architecture, No.27, Thayanoor village, Trichy, Tamil Nadu, India, e-mail: godwinarchitect@gmail.com

Victor Dariienko, Assoc. Prof., PhD. tech. sci. Central Ukrainian National Technical University, Kropyvnytskyi, Ukraine e-mail:vvdarienko@gmail.com

\title{
Architectural and constructive decisions of a triangular reinforced concrete arch with a self-stressed steel brace
}

The article describes the influence of overall dimensions, namely the ratio of lifting height to the span of the triangular reinforced concrete arch of the coating, to the change in internal forces in its cross sections. The change of axial force in steel rods and reinforced concrete half-panels and the change of bending moment in reinforced concrete half-panels depending on the angle of inclination of roof are determined. According to the obtained values of the effort, the required diameters of the working reinforcement and its cost are determined. Triangular reinforced concrete arch of a covering, self-stressed brace, architectural and constructive decisions 
О.В. Семко, проф., д-р техн. наук, А.В. Гасенко, доц., канд. техн. наук, О.Г. Фенко, доц., канд. техн. наук

Навчально-науковий інститут Архітектури та будівництва Національного університету «Полтавська політехніка імені Юрія Кондратюка», м. Полтава, Украӥна

Дж Годвін Еммануель Б. Арх., докторант, доц., наук. співроб.

C.A.R.E. Школа архітектури, №27, село Thaуапоо, Тричі, Таміл Наду, Індія

B.В. Дарієнко, доц., канд. техн. наук

Центральноукрайнський національний технічний університет, м. Кропивницький, Украйна

\section{Архитектурно-конструктивные решения треугольной железобетонной арки с самонапряженной стальной затяжкой}

В статье описано влияние габаритных размеров, а именно отношение высоты подъема к пролету треугольной железобетонной арки покрытия, на изменение внутренних усилий в ее сечениях и расхода материалов на ее изготовление. Определено изменение продольной силы в стальном тяже и железобетонных полупанелях, а также изменение изгибающего момента в железобетонных полупанелях в зависимости от угла наклона кровли. По полученным значениям усилий определены необходимые диаметры рабочего армирования и его стоимость.

треугольная железобетонная арка покрытия, самонапряженная затяжка, архитектурноконструктивные решения

Statement of the problem. All buildings and structures must meet the requirements of expediency, functionality, technical, operational, architectural, economic, environmental, special [1]. These requirements should be addressed simultaneously, constantly analyzing the impact of a decision on ensuring compliance with each of the requirements. For example, ensuring the architectural uniqueness of a building immediately affects the cost of its construction. At the same time, it is necessary to monitor the impact of the results of engineering calculations on the change of architectural and design decisions.

An analysis of recent research and publications that have begun to address this issue. Sometimes it is necessary to erect a building in a very limited time. In this case, economy and industriality play a crucial role in relation to other requirements. As a result, a whole class of so-called "prefabricated buildings" emerged. The scope of operation of prefabricated buildings is often limited to industrial buildings for agricultural or warehousing purposes. However, during the reconstruction and redevelopment of these buildings, they may perform another purpose [2]. For example, public buildings for trade and entertainment purposes, residential buildings of dormitory type, etc.

One of the most common building materials is reinforced concrete due to the lower cost compared to other materials and a sufficient level of fire resistance. Precast concrete provides at a fairly high level the requirements of industry and economy. It is possible to construct buildings of any shape in the plan from monolithic reinforced concrete. Such buildings can have any architectural and planning decision [3].

Prefabricated buildings can have a wall or frame structural scheme. Figures 1 and 2 show prefabricated buildings with a wall structural scheme. In this case, wall and roof panels perform load-bearing and enclosing functions. They are subject to the requirements of strength, rigidity, stability, insulation [4]. In this case, very often wall and roof panels are made multilayer: heavy reinforced concrete performs load-bearing functions, and porous cellular concrete or a layer of mineral wool insulation performs thermal insulation functions. 


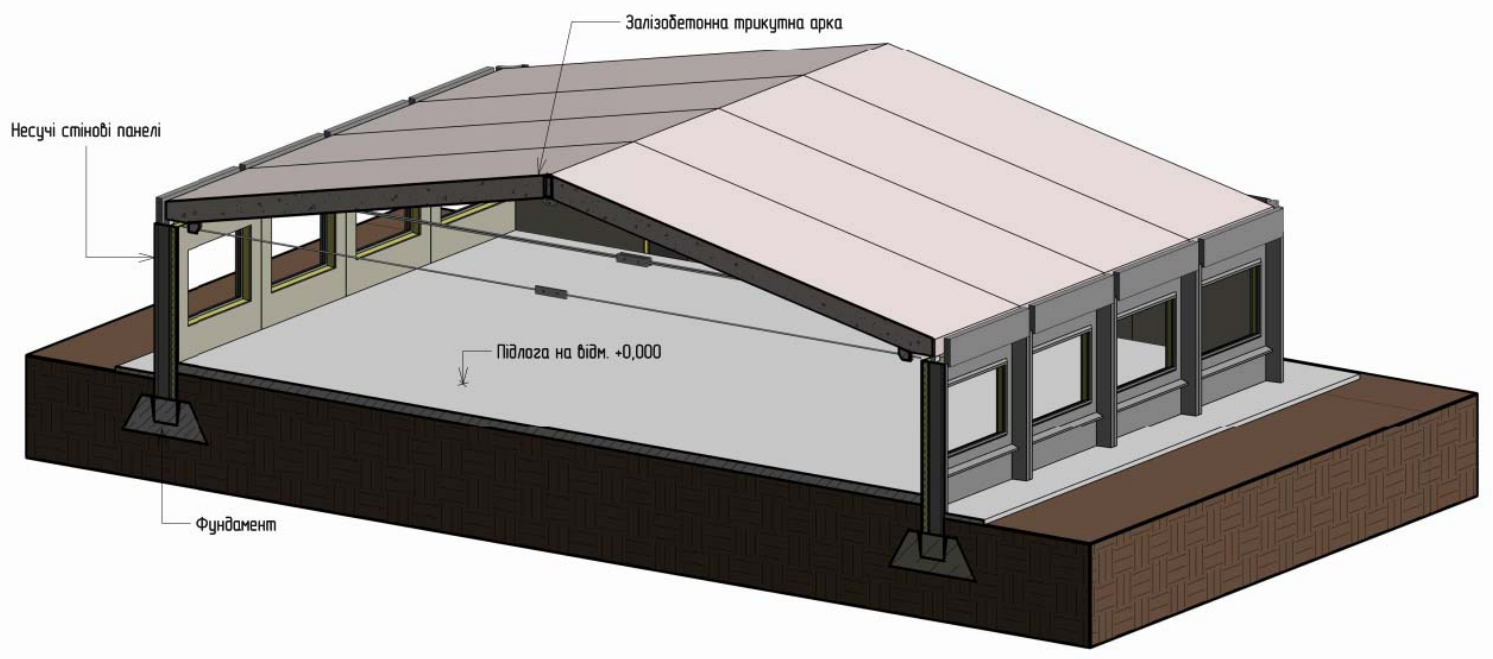

Figure 1 - Wall structural scheme of prefabricated buildings

Source: developed by the authors
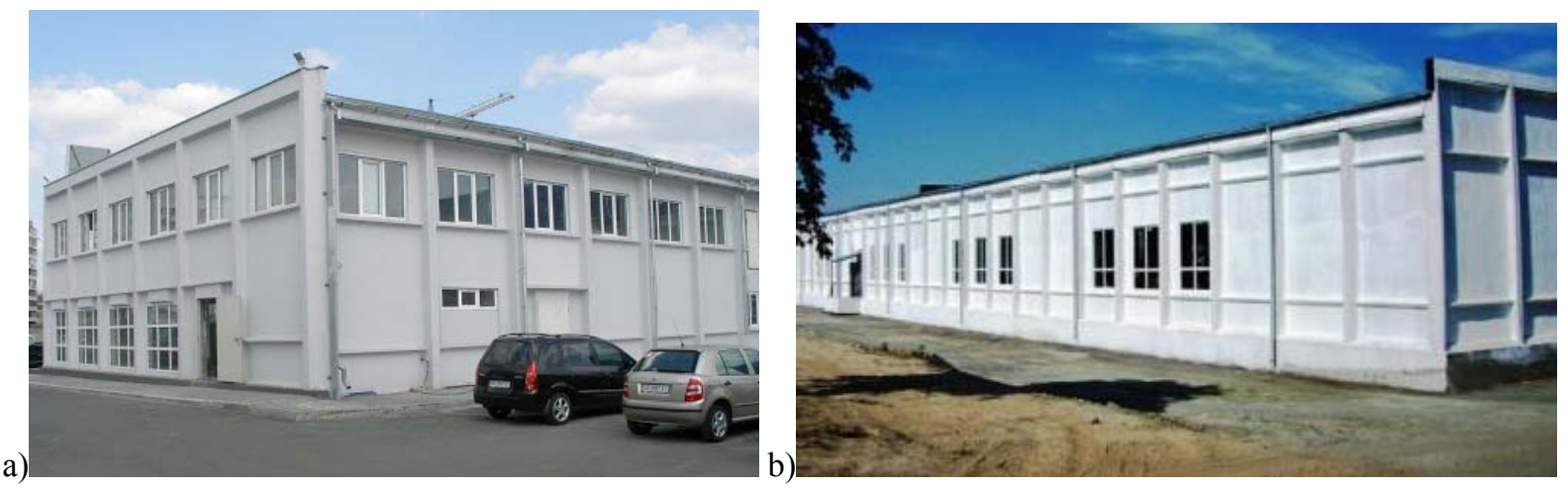

Figure 2 - Examples of prefabricated reinforced concrete buildings with a wall structural scheme: a) administrative building; b) logistics complex

Source: photos from internet sites

The advantages of such a constructive scheme include a simplified installation process due to the smaller number of building elements (absence of columns and crossbars) and the possibility of manufacturing panels in the same standard inventory formwork. However, in this case, the wall and roof panels must have increased strength, which is provided by the installation of additional reinforcing bars and increase the thickness of the concrete shelve. The elements of the panels in this case work on complex types of deformation [5].

Figures 3 and 4 show prefabricated buildings with a frame structural scheme. In this case, the supporting functions are columns and crossbars, or L-shaped frames, and wall and roof panels perform only fencing functions [6]. The advantages of such a structural scheme include a relatively simple course of design work by generating the external load to a linear or point scheme [7, 8]. Also in this case, wall and roof panels have less weight. The disadvantages, as mentioned above, include a larger number of mounting elements. To prevent the destruction of linear load-bearing elements (columns, crossbars and L-shaped frames) it is necessary to provide special individual conditions for their transportation and installation. 


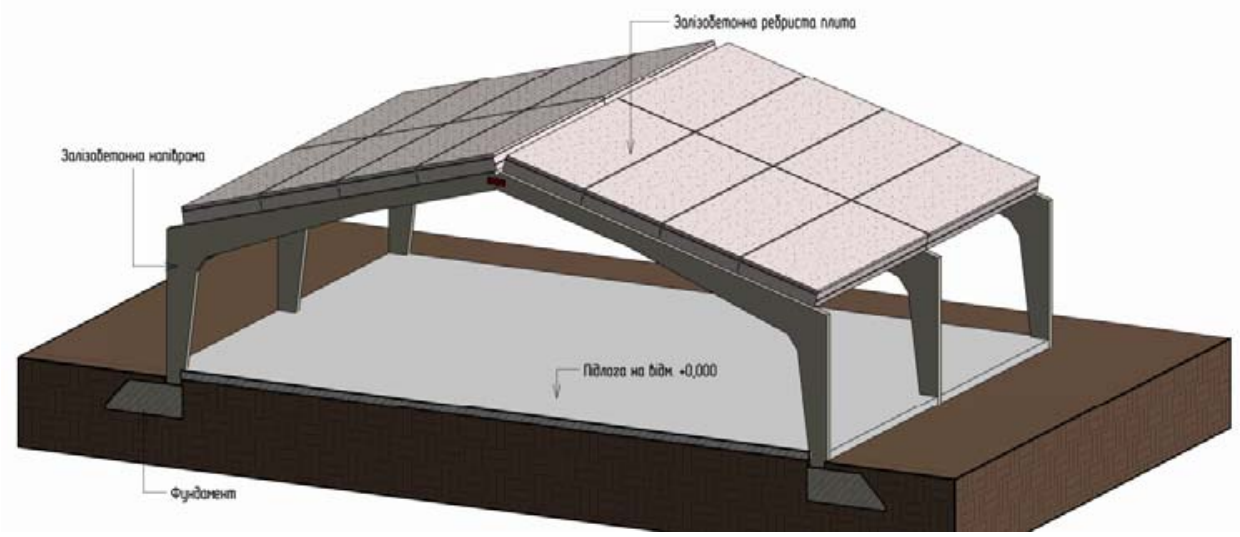

Figure 3 - Frame construction diagram of prefabricated buildings

Source: developed by the authors
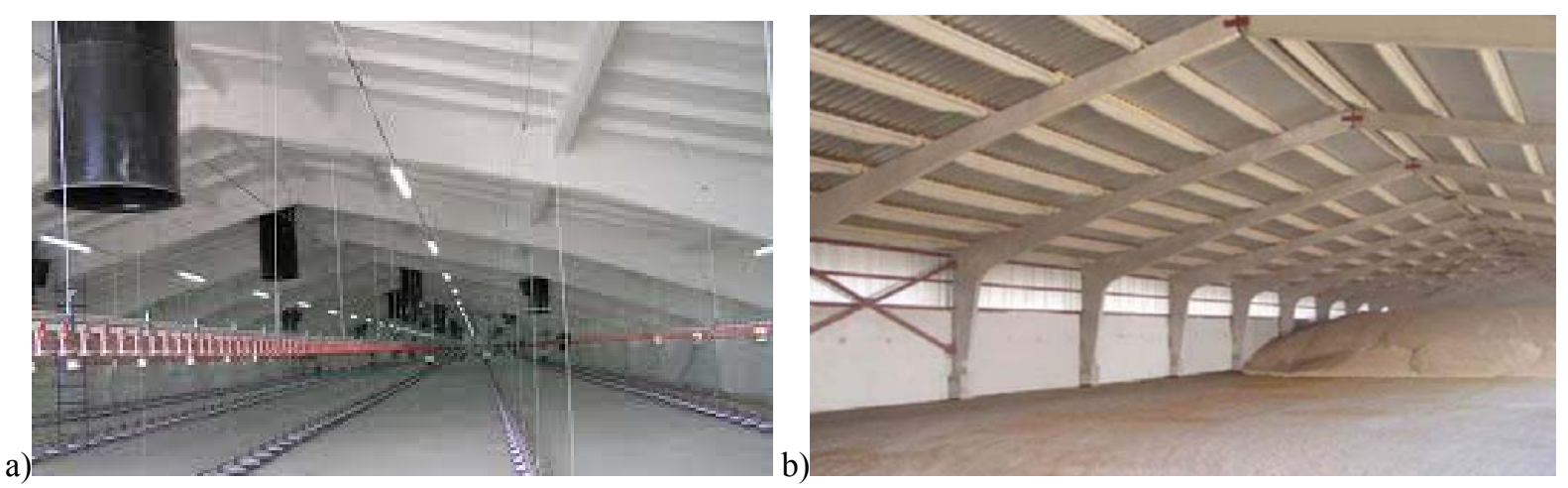

Figure 4 - Examples of prefabricated reinforced concrete buildings with a frame structural scheme:

b) poultry farm; б) granary

Source: photos from internet sites

Highlighting previously unsolved parts of the general problem to which this article is devoted. Of interest for in-depth research is the influence of the roof angle on the internal forces in the roof structures of prefabricated buildings, which has a direct impact on the crosssectional dimensions of the elements and the cost of materials for the manufacture of structures [9].

The purpose of this work is to identify the influence of the slope of the roof on the cost of materials for the manufacture of reinforced concrete ribbed panels covering prefabricated buildings wall structural scheme. A triangular reinforced concrete arch with a self-stressed steel puff was used as the coating panel (see Fig. 1). This roofing panel consists of two reinforced concrete ribbed complex half-panels, combined into a triangular arch with steel braces (see Fig. 5). The panel has embedded parts for support on wall panels, fastening of puffs, formation of a ridge knot, and also for association of panels among themselves for the purpose of formation of a uniform hard disk of a covering. The panel is transported in the form of a set of two reinforced concrete half-panels and four elements of braces [10].

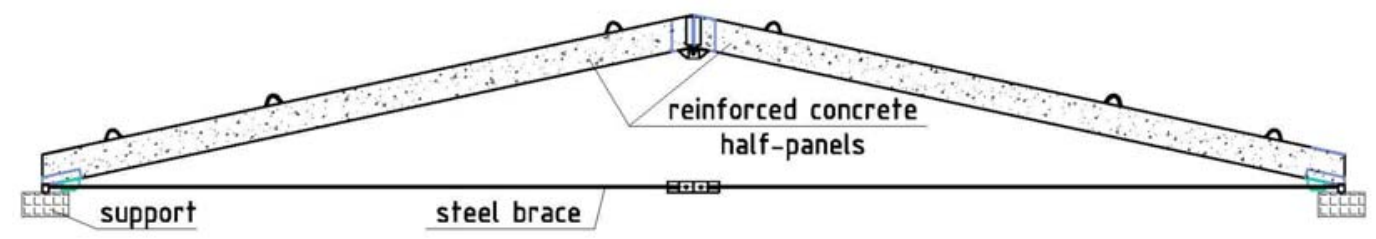

Figure 5-General view of a reinforced concrete triangular arch with a brace

Source: developed by the authors 
Presentation of the main material of the study with a full justification of the obtained scientific results. When solving this task, it is necessary to select the cross section of the elements of the reinforced concrete triangular arch with a puff with different angles of the roof slabs. In our opinion, we can distinguish the following seven main stages of design and engineering work:

1) drawing up of calculation schemes of work of a triangular reinforced concrete arch of a covering as a part of a skeleton. At this stage, determine the overall (planned and height) dimensions of the coating structure in the axes, make schemes of loading and fixing (points or sites of distribution of boundary conditions), as well as determine the nature of the connection elements (rigid or hinged connection) [11];

2) collection of loads on the structure taking into account the reliability coefficients according to the limit value of loads and load combination coefficients. Loads must be distinguished into permanent and temporary [12];

3) static calculation of the coating structure (determination of internal forces in the cross sections of structural elements). Determination of dangerous sections;

4) according to the design task to determine the calculated values of strength used in the designed triangular reinforced concrete arch with self-stressed steel tightening materials, coefficients of operating conditions of structural elements and reliability coefficients for the responsibility of the building or structure as a whole;

5) selection of sizes and shapes of cross-sections of elements of a triangular reinforced concrete arch from the conditions of strength and rigidity for the specified types of deformations, namely the compressed-bent reinforced concrete panel and the stretched brace;

6) determination of the main geometrical characteristics of the resulted sections with the chosen sizes;

7) in case of necessity of adjustment of calculation schemes of a triangular reinforced concrete arch taking into account possible shift of the central axes of section of elements, the subsequent specification of internal efforts in sections of elements and check of bearing capacity of elements (with the sizes already selected in point 5).

From the given order of designing it is obvious that each stage of design works influences others and cannot be replaced by others.

According to the above order of works, after drawing up of calculation schemes the static calculation of a triangular arch at various angles of an inclination of plates of a covering was carried out. The transformation of a triangular arch with increasing angle is shown in Figure 6.

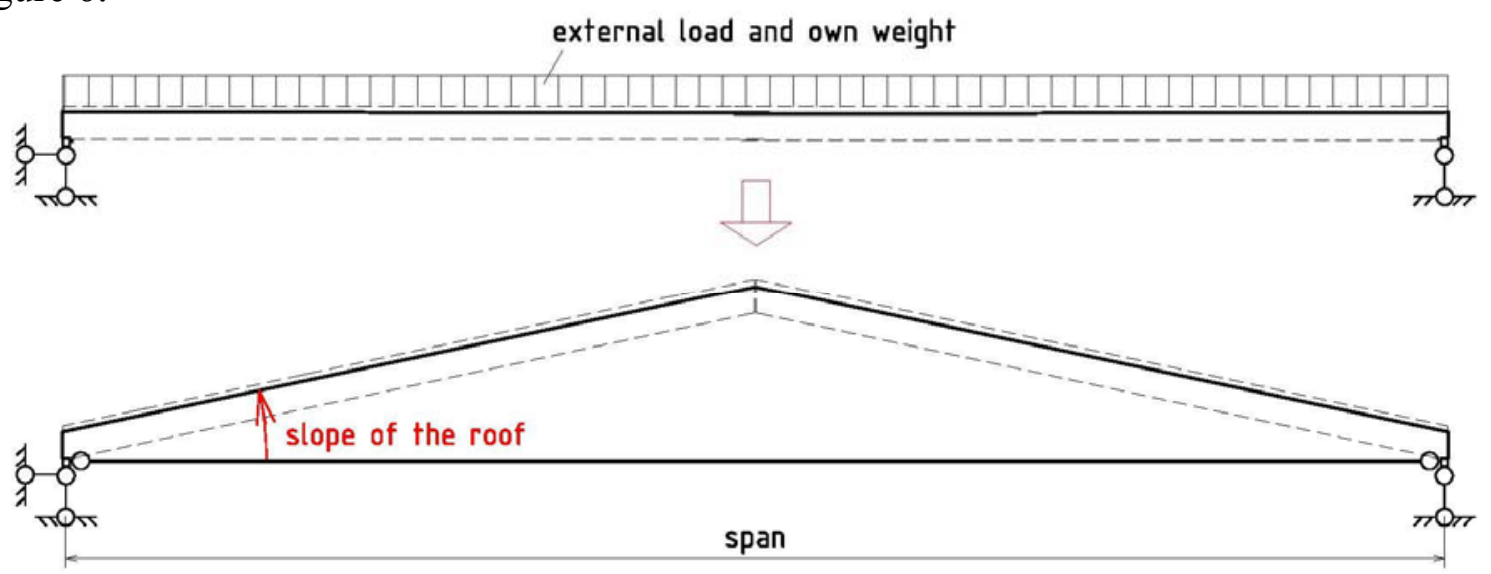

Figure 6 - Transformation of a reinforced concrete triangular arch with an brace at increase in a roof slope angle Source: developed by the authors 
As a result of the static calculation, the internal forces in the cross sections of the elements of the reinforced concrete triangular arch with a steel brace when changing the angle of inclination from zero to almost 90 degrees. According to the obtained data for a visual comparison of the calculation results, graphs of changes in the two main internal forces depending on the angle of the roof were constructed.

Figure 7 shows a graph of the change in longitudinal force, namely the tensile force of the steel brace (blue) and the compression force of the reinforced concrete panel of the upper arch belt (yellow). It should be noted that the graph shows the maximum values of the compressive longitudinal force of the reinforced concrete panel in the cornice node. By the ridge of the building, the longitudinal force decreased and the more intense, the greater the slope of the roof.

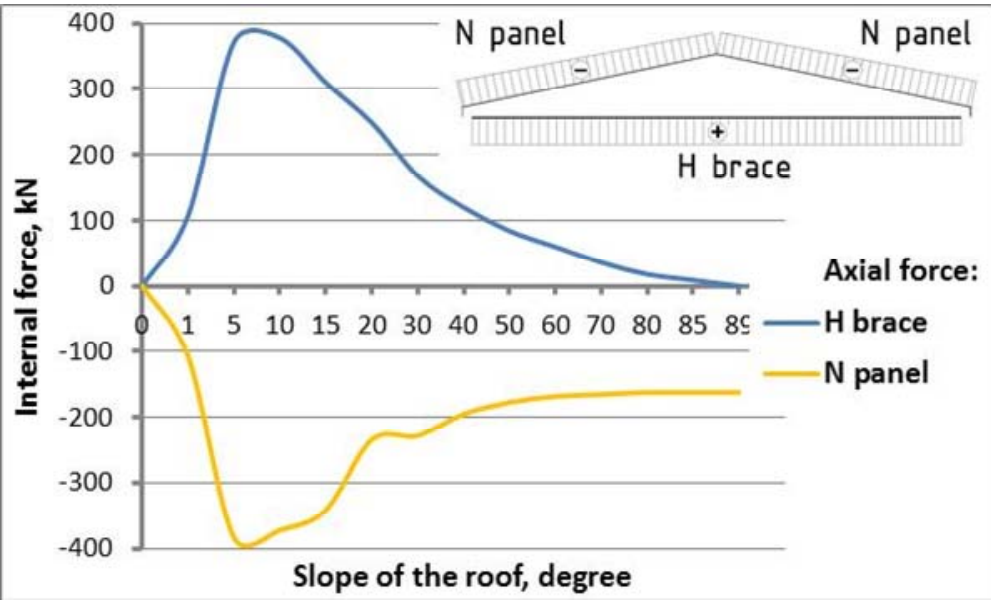

Figure 7 - Graph of change of longitudinal force in cross sections of a steel brace and the reinforced concrete panel depending on a roof slope

Source: developed by the authors

Figure 8 shows a graph of the change in bending moment depending on the angle of the roof. The graph shows two dependencies. The first dependence shows the change in the maximum bending moment, which causes tension in the lower fibers of the panel. At small angles of the roof (up to 5 degrees), this moment takes the maximum value in the middle of the span. At a larger angle, the moment takes the maximum values in the two half-panels symmetrically (see Fig. 8). The second dependence shows the change in bending moment always in the ridge of the arch. When the roof is tilted more than 15 degrees in the stretched fibers of the roof ridges are in the upper fibers of the panel.

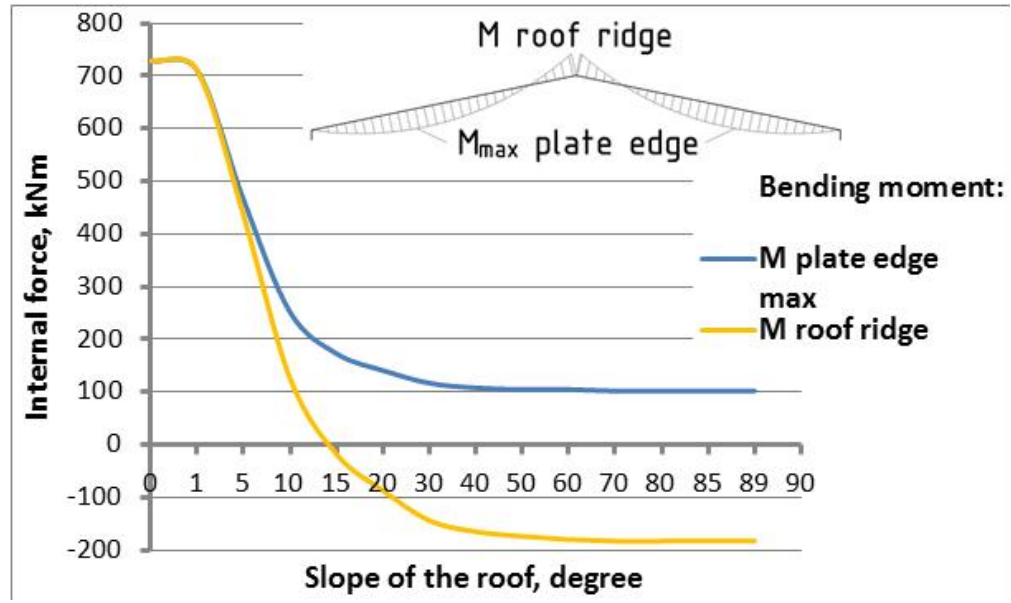

Figure 8 - Graph of change of bending moments in cross sections of the reinforced concrete panel depending on a roof slope 
According to item 5 of the above-stated stages of carrying out design works after definition of internal efforts in sections of elements of a reinforced concrete arch with an brace, necessary diameters of cores of reinforced concrete half-panels and a steel brace were selected. The results of selection of diameters of working reinforcing bars in each edge of half-panels depending on a roof angle are shown in figure 9. At a roof angle more than 15 degrees due to tensile forces in the upper fibers of half-panels, it is necessary to install working reinforcement in this panel part. The cross-section of the concrete part (shelf thickness, cross-section and pitch of ribs, structural reinforcement) was accepted for design reasons.
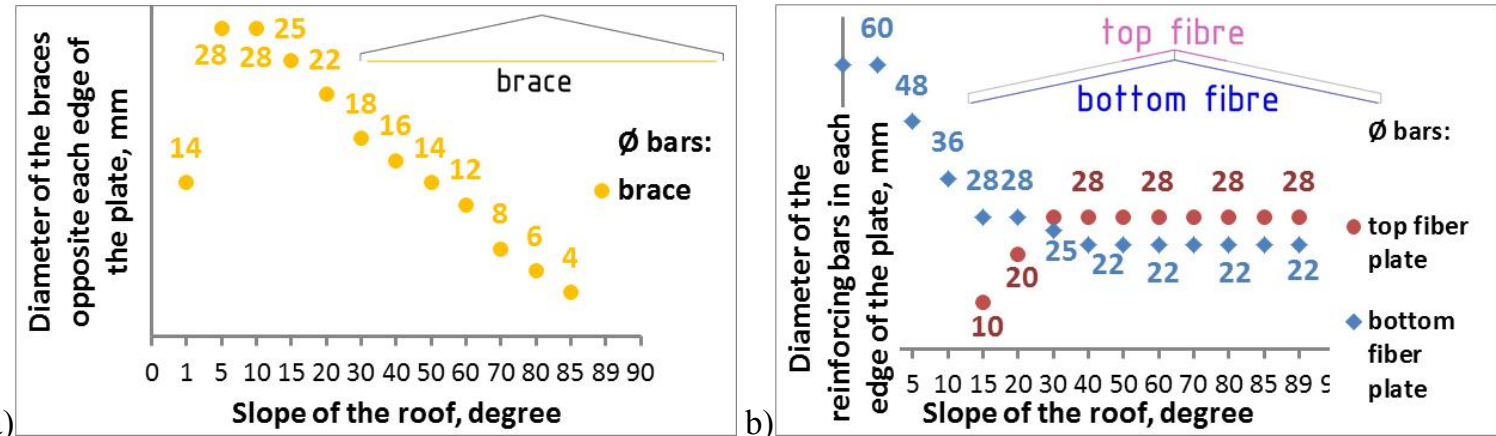

Figure 9 - Required diameters of steel bars in reinforced concrete half-panels (a) and braces (b) depending on the slope of the roof

Source: developed by the authors

The last stage of the work was to determine the cost of a reinforced concrete roof panel with a steel brace depending on the angle of the roof. To simplify the process of solving the problem, the cross section of reinforced concrete half-panels was reduced to the simplified T-section (see Fig. 10). The cost of the roof panel includes the cost of working reinforcing bars, steel brace at the bottom of the half-panels and the simplified section of concrete as of spring 2020. Figure 11 shows the results of calculating the cost of separate steel bars and concrete of the roof panel depending on the angle of the roof.

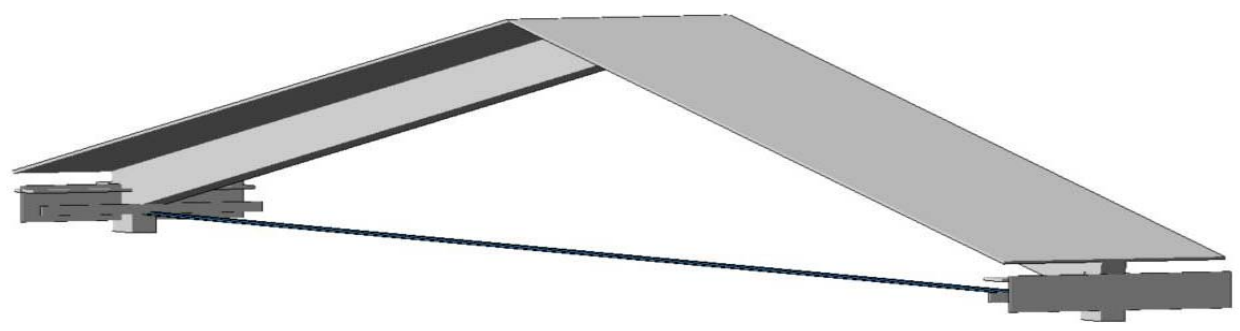

Figure 10 - Simplified section of reinforced concrete roof panel

Source: developed by the authors

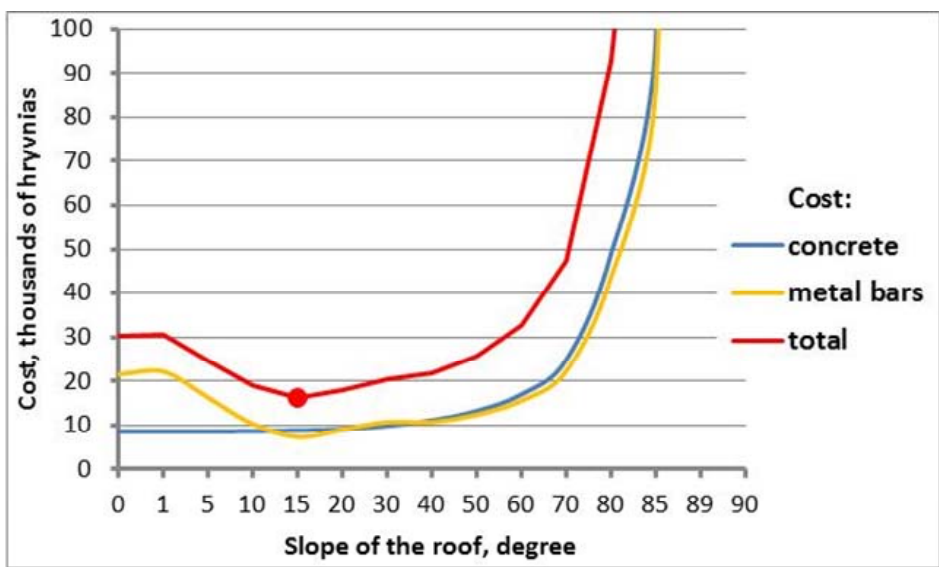

Figure 11 - Graph of change of cost of a roofing panel depending on a roof slope Source: developed by the authors 
Conclusions from this study. As can be seen from the results of the study shown in Figure 11, the optimal angle of inclination of the roof is 15 degrees. At this angle of the roof, the cost of materials (reinforcing bars and concrete), using which the strength and rigidity of the roof panel is provided, the lowest. It should be noted that this slope of the roof is also recommended when installing roofs with a small slope of profiled flooring or metal tiles. At an angle of inclination of the roof of 10-20 degrees on the schedule of costs for steel rods of reinforcement there is a descent, which is explained by the minimum bending moment in the ridge of the roof panel and the lack of tension stress in the upper fibers of the half-panels. When the angle of the roof is more than 40 degrees, the cost of concrete increases sharply, as the length of the half-panels increases.

An interesting area of further research is ways to reduce the flight moment, for example, due to the emergence of reference moments in the eaves. This reference moment can be created by increasing the shoulder of the pair of forces from the puff to the neutral axis of the compressed zone of concrete.

\section{References}

1. Semko, O.V., Hasenko, A.V., Kyrychenko, V.A. \& Sirobaba, V.O. (2020). The rational parameters of the civil building steel frame with struts. Proceedings of the 2nd International Conference on Building Innovations. - Part of the Lecture Notes in Civil Engineering book series (LNCE, volume 73). First Online: 14 June 2020. (pp. 235 - 243) [in English].

2. Rubanets, O. (2019). Transformation concept "Information technologies" in modern scientific discourse. Transfer of Innovative Technologies, Vol.2, No.1, 60-68 [in English].

3. Pavlikov, A.M., Mykytenko, S.M. \& Hasenko, A.V. (2018) Effective structural system for the construction of affordable housing. International Journal of Engineering \& Technology: Publisher of International Academic Journals. Science Publishing Corporation, RAK Free Trade Zone, Vol 7, No 3.2). 291-298. DOI: 10.14419/ijet.v7i3.2.14422 [in English].

4. Skoruk, O. (2016). Mitsnist' ta trishchynostiykist' stalefibrobetonnykh plyt, opertykh po konturu pry povtornykh navantazhennyakh [Strength and crack resistance of reinforced concrete slabs supported on the contour under repeated loads]. Pidvodni tekhnolohiyi: promyslova ta tsyvil'na inzheneriya Underwater technologies: industrial and civil engineering, Vol. 03. 83-94 [in Ukranian].

5. Pavlikov, A.M. \& Yurko, P.A. (2011). Rozv'yazannya zadach mitsnosti pozatsentrovo stysnutykh zalizobetonnykh elementiv u normal'nomu pererizi na osnovi neliniynoyi diahramy stanu betonu [Solving strength problems of eccentric compressed reinforced concrete elements in standard section basis on nonlinear concrete state diagram]. Zbirnyk naukovykh prats' (haluzeve mashynobud., bud-vo) / Poltav. nats. tekhn. un-t im. Yuriya Kondratyuka - Collection of scientific works (branch machine-building., Building) / Poltava. nats tech. Yuri Kondratyuk Un-t, Vol.1 (29). 61-65 [in Ukranian].

6. Pershakov, V.M. (2007). Karkasni budinki z trisharnirnih zalizobetonnih ram [Skeleton structures with three-hinged concrete frames]: [monograph]. K.: Knyzhkove vydavnytstvo NAU [in Ukranian].

7. Azizov T., Kochkarev D. \& Galinska T. (2020). Reinforced concrete rod elements stiffness considering concrete nonlinear properties. Lecture Notes in Civil Engineering, 47: 1-6. https://doi.org/10.1007/978-3030-27011-7_1 [in English].

8. Hasenko, A.V., Yurko, I.A., Fenko, O.G. \& Yurko, P.A. (2017). Causes of the eccentric compression reinforced concrete elements fixed joint stanchion and rafter gable frame of agricultural buildings. The International Scientific Periodical Journal "Modern Technology and Innovative Technologies", Issue №2, Vol.2. 126-129. DOI: 10.21893/2567-5273.2017-02-02-033 [in English].

9. Krutybich, O.V., Semko, O.V. \& Hasenko, A.V. (2020). Innovatsiyni tekhnolohiyi u modelyuvanni rozrakhunkovykh skhem samonapruzhenoyi stalezalizobetonnoyi arky [Innovative technologies in modeling of calculation schemes of self-stressed reinforced concrete arch]. Zbirnyk materialiv VI mizhnarodnoyi naukovo-praktychnoyi konferentsiyi «Transfer of Innovative Technologies 2020» - VI International Scientific and Practical Conference "Transfer of Innovative Technologies 2020". 38-39. DOI: 10.32347/tit2020.conf.06 [in Ukranian].

10. Seriya 7011. Zhelezobetonnyye sbornyye bystromontiruyemyye zdaniya s proletami $18 \mathrm{~m}$ [Reinforced concrete prefabricated buildings with 18 m spans] [in Russian].

11. Cherednikov V., Voskobiinyk O. \& Cherednikova O. (2017). Evaluation of the warping model for analysis of polystyrene concrete slabs with profiled steel sheeting. Periodica Polytechnica Civil Engineering 61(3). 483-490 [in English]. 
12. Storozhenko L., Yermolenko D. \& Gasii G. (2018). Investigation of the Deformation State of a Composite Cable Space Frame Structures with a Photogrammetric Method. International Journal of Engineering \& Technology, 7(3.2). 442-446. http://dx.doi.org/10.14419/ijet.v7i3.2.14568 [in English].

О.В. Семко, проф., д-р техн. наук, А.В. Гасенко, доц., канд. техн. наук, О.Г. Фенко, доц., канд. техн. наук

Національного університету «Полтавська політехніка імені Юрія Кондратюка», м. Полтава, Украӥна

Дж Годвін Еммануель Б. Арх., докторант, доц., наук. співроб.

C.A.R.E. Школа архітектури, №27, село Thayanoor, Тричі, Таміл Наду, Індія

В.В. Дарієнко, доц., канд. техн. наук

Центральноукраӥнський наџіональний технічний університет, м. Кропивницький, Україна

\section{Архітектурно-конструктивні рішення трикутної залізобетонної арки із самонапруженою сталевою затяжкою}

Метою даної роботи є виявлення впливу ухилу покрівлі на витрати матеріалів для виготовлення залізобетонних ребристих панелей покриття швидкомонтованих будівель стінової конструктивної схеми. У якості панелі покриття прийняти трикутну залізобетонну арку із самонапруженою сталевою затяжкою. Така покрівельна панель складається 3 двох залізобетонних ребристих комплексних напівпанелей, об'єднаних у трикутну арку за допомогою сталевих затяжок.

У статті описаний вплив габаритних розмірів, а саме відношення висоти підйому до прольоту трикутної залізобетонної арки покриття, на зміну внутрішніх зусиль в ії̈ перерізах та витрат матеріалів на iii виготовлення. Спочатку визначено поздовжню силу розтягу у сталевій затяжці та поздовжню силу стиску у напівпанелях. Потім визначено максимальні прольотні згинаючі моменти, а також згинаючі моменти у гребені покрівельної панелі. По отриманим значенням внутрішніх зусиль визначено необхідні діаметри робочого армування залізобетонних панелей. Підсумком проведеної роботи $\epsilon$ визначення сумарної вартості бетону та арматурних стержнів, що необхідні для виготовлення розглядуваної покрівельної панелі.

В результаті проведеної роботи визначено, що оптимальним є кут ухилу покрівлі 15 градусів. При такому куті ухилу покрівлі витрати на матеріали (арматурні стержні та бетон), використовуючи які міцність та жорсткість покрівельної панелі $є$ забезпеченою, найменші. Такий ухил покрівлі також $\epsilon$ рекомендованим при влаштуванні покрівель з малим ухилом із профільованого настилу чи металевої черепиці. При куті ухилу покрівлі 10-20 градусів на графіку витрат на сталеві стержні армування відмічається впадина, що пояснюється мінімальним згинаючим моментом у гребені покрівельної панелі та відсутності розтягу у верхніх волокнах напівпанелей. При куті ухилу покрівлі більше 40 градусів різко збільшуються витрати на бетон, так як збільшується довжина напівпанелей. Напрямком подальших досліджень $\epsilon$ шляхи зменшення прольотного моменту за рахунок виникнення опорних моментів.

трикутна залізобетонна арка покриття, самонапружена затяжка, архітектурно-конструктивні рішення

Одержано (Received) 25.06.2020

Прореиензовано (Reviewed) 26.08.2020

Прийнято до друку (Approved) 19.10.2020 